\title{
ANALISIS PENGUJIAN TARIK (TENSILE TEST) PADA BAJA ST37 DENGAN ALAT BANTU UKUR LOAD CELL
}

\author{
Haris Budiman \\ Teknik Mesin, Fakultas Teknik Universitas Majalengka \\ Email : harisbudimans@yahoo.com
}

\begin{abstract}
ABSTRAK
Salah satu cara untuk mengetahui sifat mekanik dari material adalah dengan cara Pengujian Tarik atau Tensile Test. Pengujian tarik akan menampilkan Kekuatan material sehingga bisa merancang suatu konstruksi sesuai dengan karakteristik material. Dari pengujian tarik akan diperoleh benda kerja yang putus karena proses penarikan, juga dihasilkan sebuah kurva uji tarik antara tegangan dan regangan. Kurva ini merupakan gambaran dari proses pembebanan pada benda kerja mulai dari awal penarikan hingga benda kerja itu putus.

Tujuan dari pengujian tarik ini adalah untuk mengetahu isifat-sifat mekanik suatu logam Dalam penelitian ini dikembangkan bagaimana mengolah data yang diperoleh dari pengujian tarik tersebut menjadi sebuah kurva tegangan regangan. Data-data yang diperoleh tersebut berupa besarnya pembebanan, besarnya perpanjangan dan perubahan luas penampang yang terjadi pada benda kerja. Pembebanan dan perubahan panjang benda kerja inilah yang nantinya akan dikonversikan ke dalam kurva uji tarik. Perancangan mesin uji tarik dipasang alat bantu yang sangat penting yaitu load cell, dengan fungsi untuk mendeteksi besarnya perubahan dimensi jarak yang disebabkan oleh suatu elemen gaya, sehingga dapat menghasilkan sebuah kurva tegangan-regangan yang akan menginformasikan berapa kekuatan tarik tarik benda yang diuji tarik.
\end{abstract}

\section{Kata kunci : Uji Tarik, Tensile Test, Ioad Cell, Tegangan, Regangan}

\section{PENDAHULUAN}

Pengujian tarik merupakan salah satu pengujian material yang paling banyak dilakukan di dunia industri. Karena pengujian ini terbilang yang paling mudah dan banyak data yang bias diambil dari pengujian ini. Diantaranya yang bisa didapat dari pengujian tarik ini adalah Kekuatan tarik (Ultimate Tensile Strenght), Kekuatan mulur (Yield Strenght or Yield Point), Elongasi (Elongation), Elastisitas (Elasticity) dan Pengurangan luas penampang (Reduction of Area).

Seiring dengan berkembangnya teknologi, maka pada saat ini mesin uji tarik dilengkapi dengan perangkat-perangkat elektronik untuk memudahkan dalam menganalisa data yang diperoleh. Load Cell merupakan salah satu perangkat elektronik yang digunakan sebagai perangkat tambahan pada mesin ujitarik. Load Cell menggunakan system perangkat pengolahan data. Karena bagaimanapun juga faktor manusia sangat dominan untuk memperoleh hasil dari pengujian ini.

Tujuan dari penelitian ini adalah menentukan dan menganalisa tegangan maksimum material pada suatu spesimen benda uji berupa gaya tarik, tegangan, tegangan, dan kurva uji tarik dari hasil pengujian tarik pada spesimen baja.

Batasan dari penelitian ini yaitu Pengujian dilakukan pada spesimen Baja ST-37 dan analisis hasil pengujian yang didapat dengan menngunakan alat ukur Load Cell.

\section{DASAR TEORI \\ 2.1 Pengujian Tarik}

Salah satuhal yang bisa menyebabkan kegagalan pada elemen sebuah konstruksi mesin adalah beban yang bekerja pada elemen mesin besarnya melebihi kekuatan material. Kekuatan merupakan sifat yang dimiliki oleh setiap material.Kekuatan pada material dibagi menjadi dua bagian yaitu kekuatan tarik dan kekuatan mulur. Kekuatan material bias diperoleh dari sebuah pengujian yang dikenal dengan nama uji tarik. Dari pengujian itu selain diperoleh specimen kerja yang putus karena proses penarikan, juga dihasilkan sebuah kurva uji tarik. Kurva ini merupakan gambaran dari proses pembebanan pada specimen kerja mulai dari awal penarikan hingga specimen kerja itu putus. 


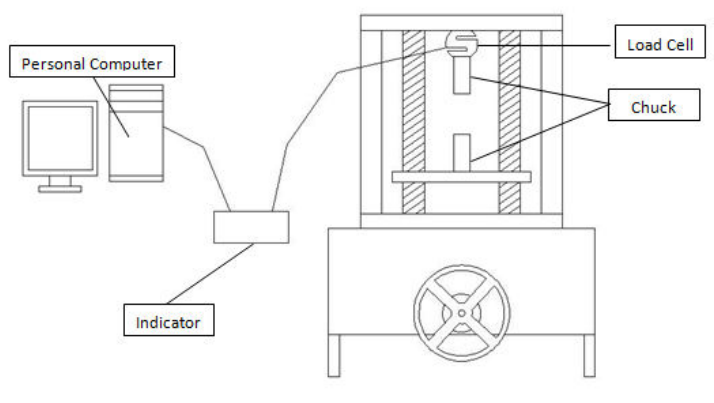

Gambar 2.1 Skema peralatan yang digunakan dalam uji tarik

Dari gambar 2.1 dapat dilihat beberapa komponen utama yang terdapat pada mesin uji tarik. Komponen utama tersebut terdiri dari alat pencatat gaya (load cell), alat pencatat pertammaterial panjang spesimen (extensometer), batang penarik (moving crosshead), dan spesimen. Load cell digunakan untuk mencatat besarnya pembebanan $(\mathrm{F})$ yang dialami oleh spesimen, sedangkan extensometer digunakan untuk mencatat besarnya pertammaterial panjang $(\Delta \mathrm{L})$ yang terjadi pada spesimen. Hubungan antara gaya (F) terhadap pertammaterial panjang $(\Delta \mathrm{L})$ inilah yang nantinya akan dikonversikan ke dalam kurva tegangan $(\sigma)$ terhadap regangan teknik $(\mathrm{e})$.

\subsection{Spesimen Uji Tarik}

Spesimen uji tarik bentuk dan ukurannya sudah terstandar, dalam kasus-kasus tertentu dijinkan memakai bentuk dan ukuran specimen uji tidak standar. Bentuk dan ukuran specimen uji terstandar disebut juga specimen uji proporsional, dan yang tidak terstandar disebut juga specimen uji non proporsional. Bentuk penampang specimen uji dapat berbentuk lingkaran atau bentuk segi empat. Ukuran specimen uji yang iasa dipakai standar DP 5 atau DP 10.

\section{a. Kurva Uji tarik}

Setiap logam yang diuji tarik akan memperlihatkan perilaku yang berbeda dalam arti mempunyai empat besaran/parameter yang berbeda. Perbedaan perilaku itu ditunjukan dalam Gambar 2.2.

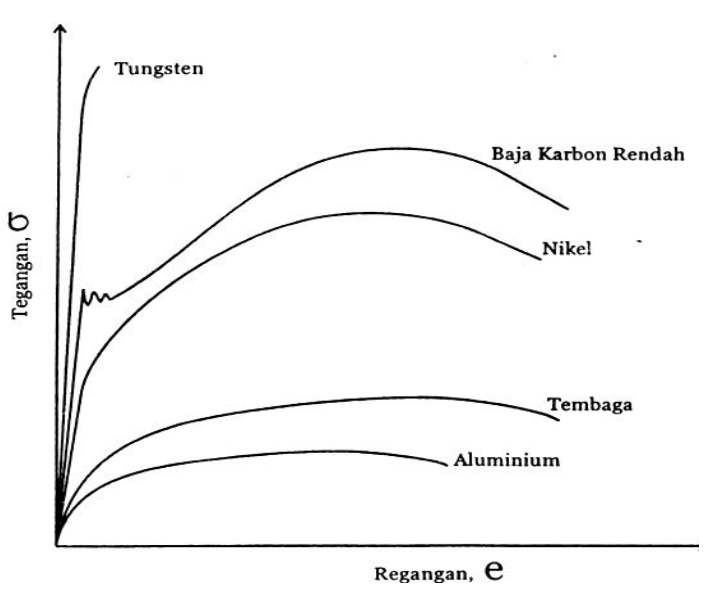

Gambar 2.2. Kurva Empat besaran/parameter yang berbeda

Kurva uji tarik dapat diperoleh beberapa sifat mekanik material. Beberapa sifat mekanik material yang dimaksud yaitu Dari kekuatan tarik, keuletan, dan elastisitas. Contoh kurva hasil uji tarik dapat dilihat pada gambar 2.3

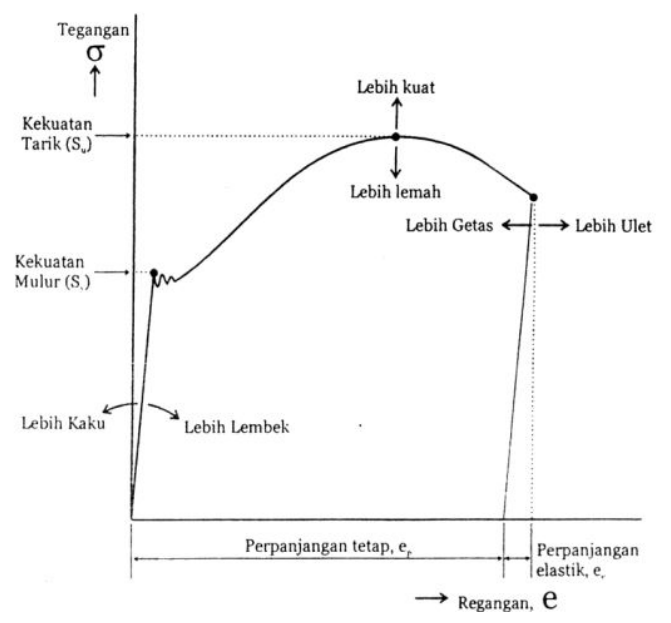

Gambar 2.3. Contoh kurva hasil uji tarik

\subsection{Pemilihan Load Cell}

Load cell adalah sebuah transducer gaya yang bekerja berdasarkan prinsip deformasi sebuah material akibat adanya tegangan mekanis yang bekerja. Untuk menentukan tegangan mekanis didasarkan pada hasil penemuan Robert Hooke, bahwa hubungan antara tegangan mekanis dan deformasi yang diakibatkan disebut regangan. Regangan ini terjadi pada lapisan kulit dari material sehingga memungkinkan untuk diukur menggunakan sensor regangan atau strain gage. 
Strain gage adalah transducer pasif yang mengubah suatu pergeseran mekanis menjadi perumaterial tahanan. Strain gage logam dibuat dari kawat tahanan berdiameter kecil atau lembaran-lembaran kawat tipis yang di-etsa. Tahanan dari foil kawat atau logam ini berubah terhadap panjang jika material padamana "gage" disatukan mengalami tarikan atau tekanan. Perumaterial tahanan ini sebanding dengan regangan yang diberikan dan diukur dengan sebuah jembatan wheat-stone yang dipakai secara khusus. Sensitivitas sebuah strain gage dijelaskan dengan suatu karakteristik yang disebut gage factor, yang didefinisikan sebagai perumaterial satuan tahanan dibagi perumaterial satuan panjang.

\section{METODE PENELITIAN}

Ada beberapa tahap yang harus dilakukan dalam kegiatan pengujian ini. Untuk mempermudah dan menghasilkan perhitungan yang akurat, disusun diagram alir sebagai urutan proses yang dilakukan dalam melakukan pengujian tarik. Diagram alir itu ditunjukan sebagai berikut:

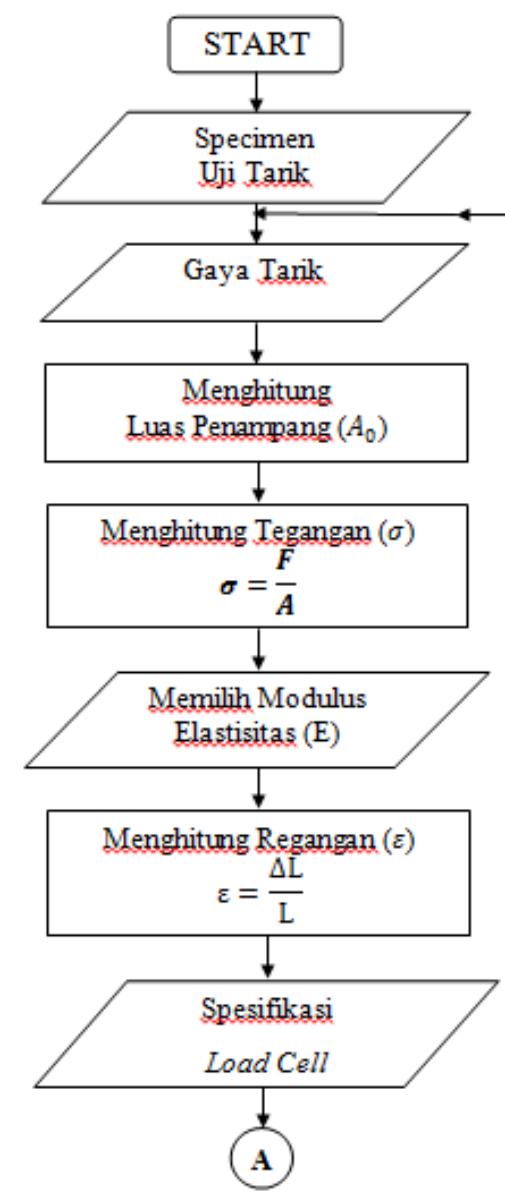

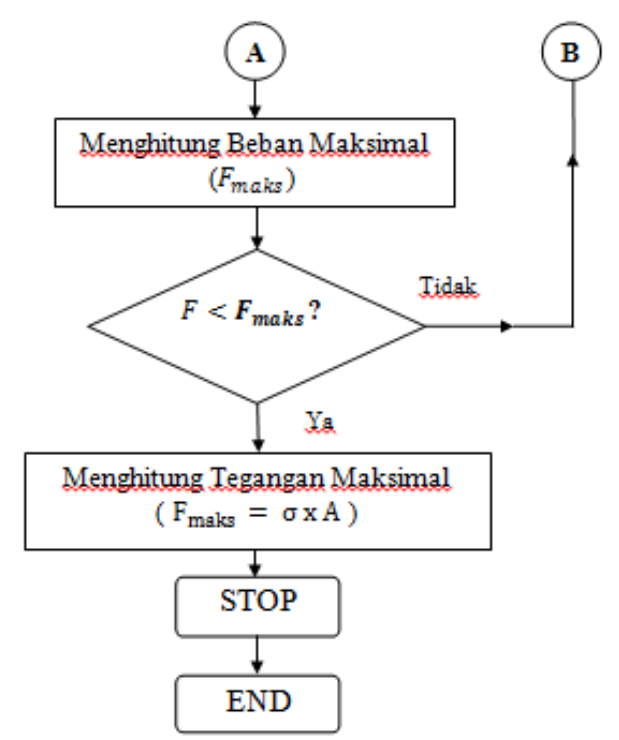

IV. PROSES PENGUJIAN TARIK

\subsection{Persiapan pengujian tarik}

a) Chuck

Chuck memiliki peranan penting yang merupakan komponen mesin uji tarik yang berfungsi sebagai pemegang benda kerja atau spesimen. Oleh karena itu sebelum melakukan pengecekan terlebih dahulu terhadap chuck.

b) Tuas pemutar

Tuas pemutar berfungsi sebagai pemutar atau penggerak poros, dimana poros ini memutar roda-roda gigi pada mesin uji tarik yang berfungsi menarik chuck bagian bawah sehingga benda uji ikut tertarik. Pada saat benda uji tertarik disinilah terjadi pembebanan tarik pada benda uji.

c) Load Cell

Load Cell berfungsi sebagai pengukur tegangan tarik atau pembebanan yang terjadi pada spesimen. Pemasangan Load Cell harus sesumbu dengan chuck bagian atas dan bawah.

d) Indikator

Indikator berfungsi menampilkan beban tarik dari Load Cell dan sebagai penghubung ke komputer.

e) Perakitan indikator ke komputer

Load cell yang sudah terpasang ke indikator sebenarnya sudah bisa dikatakan cukup, akan tetapi untuk lebih efisien, maka perlu ditambahkannya memory sebagai perekam hasil pembebanan uji tarik yang telah dilakukan. Dalam tugas 
akhir ini, dirancang menggunakan komputer sebagai perekam hasil uji tarik.

f) Langkah - langkah pengujian Langkah-langkah pengujian tarik adalah sebagai berikut:

1. Lakukan pengecekan terhadap mesin uji tarik.

2. ettimg atau lakukan pengaturan pada indicator, seperti ketelitian Load Cell pada tampilan indicator.

3. Lakukan pengkalibrasian terhadap alat ukur Load Cell ter hadap indicator.

4. Setting indicator, seperti satuan yang digunakan, baud rate dan lain-lain.

5. Hubungkan kabel RS232 dari indicator ke komputer.

6. Setting pada komputer sehingga indicator dapat terbaca.

7. Siapkan alat ukur seperti jangka sorong atau micrometer.

8. Siapkan spesimen yang akan di uji, yaitu dengan mengampelas spesimen, karena spesimen uji harus halus dan bersih.

9. Ukur dimensi spesimen yang akan di uji, seperti panjang dan diameternya.

10. Pasangkan spesimen pada mesin uji tarik, pasangkan kedua ujungnya dengan benar dan tegak lurus.

11. Lakukan pemberian beban tarik pada spesimen

12. Penarikan atau pemberian beban tarik dimulai dari nol, dengan penambahan beban secara merata agar tidak terjadi beban kejut.

13. Selama pengujian berlangsung akan terjadi pertambahan panjang dan pengecilan penampang sampai terjadinya patah atau putus.

14. Hitung berapa kali putaran tuas pemutar berputar dari awal pembebanan hingga spesimen patah.

15. Lakukan pencatatan data hasil pengujian.

16. Untuk memudahkan dalam pembuatan kurva uji tarik, sebaiknya minimal setiap lima kali putaran dicatat data perubahan panjang, diameter dan beban tariknya.

17. Setelah terjadinya patah pada spesimen atau pengujian selesai, lakukan pengukuran lagi terhadap dimensi spesimen.
18. Olah data hasil pengujian sehingga menjadi kurva uji tarik.

\section{PEMBAHASAN}

Dari hasil proses pengujian tarik akan didapatkan sifat-sifat mekanik logam dari spesimen atau bahan yang di uji tersebut.

\subsection{Data hasil uji tarik}

1. Spesimen Pertama Data pengujian tarik pada specimen pertama terlihat pada tabel 5.1 sebagai berikut:

Tabel 5.1 DataPengujian SpesimenPertama

\begin{tabular}{|c|c|c|c|c|c|}
\hline $\begin{array}{c}\text { Jum } \\
\text { lahP } \\
\text { utar } \\
\text { an }\end{array}$ & $\begin{array}{c}\text { Beba } \\
\text { nTari } \\
\mathrm{k}(\mathrm{F}) \\
\mathrm{Kg}\end{array}$ & $\begin{array}{c}\text { Dia. } \\
\text { Akhir } \\
\left(\mathrm{D}_{1}\right) \\
\mathrm{mm}\end{array}$ & $\begin{array}{c}\text { Pjng } \\
\text { Akhir } \\
\left(\mathrm{L}_{1}\right) \\
\mathrm{mm}\end{array}$ & $\begin{array}{c}\text { Teg. } \\
(\sigma) \\
\mathrm{Kg} / \mathrm{mm} \\
2\end{array}$ & $\begin{array}{c}\text { Reg. } \\
(\varepsilon)\end{array}$ \\
\hline 5 & 33 & Tetap & Tetap & 4.95 & 0 \\
\hline 10 & 42 & 2,95 & 12,20 & 6.66 & 2 \\
\hline 15 & 298 & 2,90 & 12,25 & 44.84 & 3.7 \\
\hline 20 & 393 & 2,90 & 12,80 & 61.44 & 7 \\
\hline 25 & 402 & 2,80 & 13,30 & 68.13 & 10.8 \\
\hline 30 & 419 & 2,75 & 13,90 & 73.95 & 15.8 \\
\hline 35 & 407 & 2,65 & 14,55 & 77.21 & 20.8 \\
\hline 40 & 387 & 2,05 & 15,45 & 123.51 & 28.7 \\
\hline 42 & 323 & 1,80 & 16,30 & 135.83 & 35.4 \\
\hline
\end{tabular}

Grafik tegangan regangan specimen pertama.

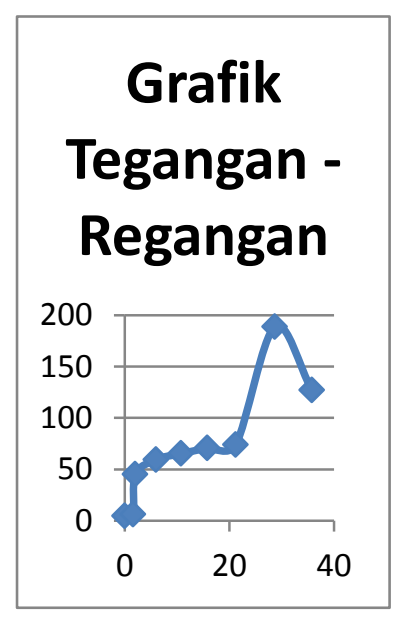

2. Spesimen kedua

Data pengujian tarik pada specimen kedua terlihat pada tabel 5.2 sebagai berikut: 
Tabel 5.2 Data Pengujian Spesimen Kedua

\begin{tabular}{|c|c|c|c|c|c|}
\hline $\begin{array}{l}\text { Jum } \\
\text { lah } \\
\text { Puta } \\
\text { ran }\end{array}$ & $\begin{array}{c}\text { Beban } \\
\text { Tarik } \\
(\mathrm{F}) \\
\mathrm{Kg}\end{array}$ & $\begin{array}{c}\text { Dia. } \\
\text { Akhir } \\
\left(D_{1}\right) \\
\mathrm{mm}\end{array}$ & $\begin{array}{c}\mathrm{Pj} \\
\text { Akhir } \\
\left(\mathrm{L}_{1}\right)\end{array}$ & $\begin{array}{c}\text { Teg. } \\
(\sigma) \\
\mathrm{Kg} / \mathrm{m}\end{array}$ & $\begin{array}{l}\text { Reg. } \\
(\varepsilon)\end{array}$ \\
\hline 5 & 35 & Tetap & Tetap & 4.95 & 0 \\
\hline 10 & 44 & 2,90 & 12,25 & 6.66 & 2 \\
\hline 15 & 296 & 2,90 & 12,45 & 44.84 & 3.7 \\
\hline 20 & 392 & 2,85 & 12,85 & 61.44 & 7 \\
\hline 25 & 404 & 2,75 & 13,30 & 68.13 & 10.8 \\
\hline 30 & 423 & 2,70 & 13,90 & 73.95 & 15.8 \\
\hline 35 & 410 & 2,60 & 14,50 & 77.21 & 20.8 \\
\hline 40 & 388 & 2,00 & 15,45 & $\begin{array}{c}123.5 \\
1\end{array}$ & 28.7 \\
\hline 44 & 326 & 1,75 & 16,25 & $\begin{array}{c}135.8 \\
3\end{array}$ & 35.4 \\
\hline
\end{tabular}

Grafik tegangan regangan specimen kedua

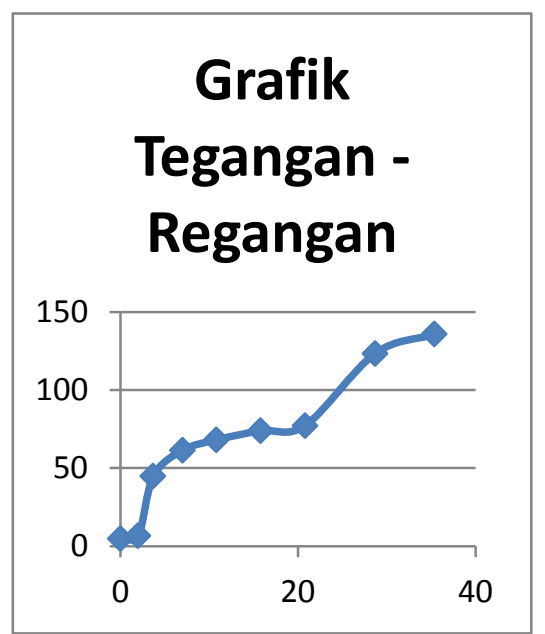

\section{KESIMPULAN}

6.1 Kesimpulan

Beberapa hal yang bisa dirumuskan untuk menjadi kesimpulan dari penelitian ini adalah sebagai berikut :

1. Data spesimen uji sesuai dengan Standar JIS

2. Hasil dari pengukuran kekuatan tarik, elongasi, dan modulus elastisitas dapat diplot pada kurva uji tarik regangan terhadap regangan.

\subsection{Saran}

Berikut beberapa saran yang perlu dilakukan untuk menyempurnakan hasil penelitian ini :

1. Lakukan kalibrasi atau sertifikasi pada lembaga resmi KAN
2. Untuk penelitian selanjutnya perlu dikembangkan peralatan yang menghasilkan kurva uji tarik yang sudah terplot di mesin uji

\section{DAFTAR PUSTAKA}

Holman, J.P,.Perpindahan Kalor, Edisi keenam.,Erlangga. Jakarta. 1995

Agriculture and Agri-Food Canada. Heat recovery for Canadian food and beverage industries. 2001. www.agr.gc.ca/cal/epub/5181e/51810007_e.html

Considine, Douglas M. Energy Technology Handbook. McGraw Hill Inc, New York. 1977.

Department of Coal Publications, Government of India. Fluidised Bed Coal-Fired Boilers

Department of Coal, India, prepared by National Productivity Council. Coal Improved Techniques for Efficiency. 1985

Elonka, Jackson M., and Alex Higgins, Steam Boiler Room Questions \& Answers, Third Edition

Energy Machine, India. Energy Machine Products, Thermic Fluid Heater:

Flowtherm series.

www.warmstream.co.in/prod-em-thermicfluid-heaters.html

Gunn, D., and Horton, R. Industrial Boilers, Longman Scientific \& Technical, New York

India Energy Bus Project, Industrial Heat Generation and Distribution. NIFES TrainingManual Issued for CECIS 10392, 1982

Jackson, J. James, Steam Boiler Operation. Prentice-Hall Inc., New Jersey. 1980.

Light Rail Transit Association, Trams for Bath. D.C. Power stations - Boilers.

www.bathtram.org/tfb/tT111.htm

National Coal Board. Fluidised Combustion of Coal. London

National Productivity Council. Efficient Operation of Boilers

Pincus, Leo I. Practical Boiler Water Treatment. McGraw Hill Inc., New York. 1962. 